\title{
Macroeconomic uncertainty, corporate governance and corporate capital structure
}

\begin{abstract}
Purpose: The purpose of this paper is to examine how corporate governance moderates the relationship between macroeconomic uncertainty and corporate capital structure. Design/methodology/approach: This paper employs the two-step system generalized method of moments regression, considering a sample of 907 listed non-financial firms from seven Asia Pacific countries during the period 2004-2014. Findings: This study finds that macroeconomic uncertainty has a significant negative impact on the capital structure decisions of firms. The results also reveal that the overall effect of macroeconomic uncertainty on capital structure among firms with better governance quality is significantly negative. The evidence suggests that corporate governance acts as an effective mechanism to curb the usage of leverage during times of high volatility. Further analysis shows that board independence, the separation between the roles of CEO and chairman of the board and blockholders' ownership are effective governance mechanisms, whereas similar observations do not hold for board size and institutional ownership. Research limitations/implications: The findings of this study may be useful to policy makers to formulate appropriate policies to mitigate the adverse effects caused by macroeconomic uncertainty. This is important because macroeconomic uncertainty may have potential destabilizing effects on a country's or region's development by jeopardizing the firms' ability to formulate sound investment, production and financing decisions. Additionally, the results suggest that good governance quality can act as a check and balance to ensure that firms use less leverage when they are facing volatility in the macroeconomic environment. These findings could help to reinforce the importance of good governance among policy makers of a country as well as managers of firms. Originality/value: The authors make the first attempt to examine the moderating effect of corporate governance on the relationship between macroeconomic uncertainty and corporate capital structure.
\end{abstract}

Keyword: Corporate governance; Capital structure; Leverage; System GMM; Macroeconomic uncertainty; Asia Pacific region 